Open Access available at: http://journals.uct.ac.za/index.php/UR

DOI 10.15641/ur-at-uct.v1i2.37

\title{
Supportive structures for play and social inclusion within an urban park: a qualitative descriptive study
}

Tessa Becker (skinnytwigs@gmail.com)

Astrid Kostner (KSTAST001@myuct.ac.za)

Elelwani Ramugondo (Elelwani.Ramugondo@uct.ac.za)

ORCID: orcid.org/0000-0002-1987-4651

Co-authors: Jenna Ashcroft, Megan Kirsten \& Kendra Neethling

Supervisor: A/Prof Elelwani Ramugondo

Health \& Rehabilitation Sciences, University of Cape Town

\begin{abstract}
This study aimed to determine the extent and the ways in which Amber Park is perceived by its users to either facilitate or hinder play and social inclusion. The study is qualitative descriptive in nature. Purposive sampling for maximum variation was used to select the 16 participants who were interviewed. Inductive reasoning was followed through open coding, allowing for the conceptualisation of raw data. This generated 15 categories, which were further collapsed into 3 themes; (a) A space for valued play (which incorporates how the park meets park users' occupational needs in a way that provides meaning and value for the users), (b) Play: disrupting class and race (which shows how play equalises power relationships in a unique way), and (c) All welcome, but... (which speaks to latent hegemonic practices and how these dictate behaviour and inclusion). These findings provide new understandings about the way in which an urban park can support valued play by meeting occupational needs, as well as mitigate racial, class and generational divides within a diverse society, and may inform inclusive policies for public spaces.
\end{abstract}

\section{Keywords:}

Play, Urban Park, Supportive Structure, Social Inclusion, Occupational Therapy 


\section{Introduction}

Play has been called the primary occupation of childhood (Knox, 2008; Wilcock, 2006) and as such should be at the heart of children's engagements (Shackell, Butler, Doyle, \& Ball, 2008). Play is described in terms which include but are not limited to 'being active', 'spontaneous', 'purposeless', 'self-initiated' and 'serious', and defined as an activity that is fun, flexible and done for its own sake (Frost \& Klein, 1979; Pellegrini, 1995). Children's use of space has changed in the last few decades, with time indoors shrinking as children are ferried to various destinations by car (Burton, 2011). Not all play is valued play and society defines and shapes through time what play is valued.

Sutton-Smith (1997) coined the concept of "play rhetorics", which express the way play is situated in context within wider value systems (Sutton-Smith, 1997; Sutton-Smith, 2006). The primary way that play is viewed in recent literature, particularly within a Western context revolves around the rhetoric of play as progress (Sutton-Smith, 1997) where parks are seen as a space to allow children to get rid of excess energy, improve motor skills, and interact with other children in an environment that is less restrictive than at home and school. This kind of play promotes children's social and cognitive development (Loukaitou-Sideris \& Sideris, 2009). The value of imaginative play increased as the notion that nature-based play has been found to allow children's imaginations to run wild (Luchs \& Fikus, 2013). Play as frivolity, which generally ridicules rules of the contemporary world, (Sutton-Smith, 1997) has been barely acknowledged. Acknowledging how play may be used to address power relations may prove very useful within a context such as post-apartheid South Africa.

\section{Methodology}

This research study was approved by the Faculty of Health Sciences Human Research Ethics Review Committee at the University of Cape Town. Qualitative descriptive research was used as it recognises the value of generating data based on personal viewpoints, contextual factors and reflexive interpretation to provide a comprehensive understanding (Tewksbury, 2009) before using more analytical 
approaches. This approach was appropriate for the study as the researchers wanted to observe what people did in the park and explain how the park facilitated play and social inclusion, as well as how the individuals in the park experienced the park itself. Participants were selected using purposive sampling for maximum variation. The selection criteria for the participants included anyone who went to the park and stayed long enough to be observed in play and socialisation (i.e. not just passing through) as well as anyone who was available for an interview. Children under the age of six were not interviewed. An attempt was made to have a sample racially representative of the Rondebosch population, in accordance with the City of Cape Town Census for Rondebosch/Rosebank (2011). Other factors were also considered such as ability, gender, age and socioeconomic status. Overall 16 participants were interviewed and 17 observation sessions recorded. The researchers were able to collect data on weekdays as well as weekends from spring to beginning of winter. Data was collected and guided by an observation checklist. The interviews were audio recorded, transcribed and then analysed into codes, categories and themes.

\section{Limitations}

Time spent in interviews was limited to avoid disrupting family and leisure time. The race and gender of the interviewers (white females) may have influenced responses from interviewees.

\section{Findings}

Three major themes emerged from the findings: "A space for valued play", "Play: Disrupting Class and Race", and "All welcome but...". that were informed by 15 categories as presented in Table 1 below. 
Table 1. Themes supported by relevant categories

\begin{tabular}{|c|c|}
\hline Themes & Categories \\
\hline A space for valued play & $\begin{array}{l}\text { Intergenerational, distraction-free zone } \\
\text { Play your age } \\
\text { A leisure space } \\
\text { Leaves room for creative play and imagination } \\
\text { Various areas for active physical play } \\
\text { A place to learn through play } \\
\text { Allows for stillness }\end{array}$ \\
\hline Play: disrupting class and race & $\begin{array}{l}\text { Segregation is learnt } \\
\text { Black Nanny, White Child } \\
\text { Park as Neutral Territory }\end{array}$ \\
\hline All welcome, but... & $\begin{array}{l}\text { Maintaining class and whiteness } \\
\text { Birds of a feather } \\
\text { "Normal" and disabled: same-same but different } \\
\text { The homeless should be seen and not heard } \\
\text { No loitering }\end{array}$ \\
\hline
\end{tabular}

\section{A Space for Valued Play}

This theme focuses on how Amber Park facilitated or hindered play engagement, and how it met specific play and occupational needs. The theme is supported by categories that reflect the idea that the park provides an area away from everyday distractions of technology, obligations and responsibilities, where play in the park facilitates quality time and interaction between generations. The theme also explores intergenerational aspects of play, providing meaning and coherence for parents, as their children engage in the play they value. The park provided an opportunity to share experiences with other family members, many of whom had come to the park at various stages of their life and utilised the park differently as they grew up. 
'It's active and we participate with her. Dad likes to push her on all the stuff, that type of thing. Definitely it's better than sitting at home or watching TV, that type of thing, so we do it often.'

'Before we had (boy's name), we would come just for a walk, but that would be...you know, we'd just do like laps around the school field, so more of like a long walk than play here, obviously.'

Parents expressed that active play was beneficial and thoroughly enjoyed by children. A group of young adults were also seen practicing slacklining, hula hooping and muay thai.

As such, active outdoor play was clearly valued by adults and was often synonymous with separation from technology.

'Get the kids away from their phones and computers.'

'Better than sitting at home or watching TV.'

There were clear rules as to which ages could play on which equipment and in which area. The researchers noticed that children found ways to use the same spaces creatively, and when inter-age group play occurred, the play was often appropriately adapted in order to suit the level of all who were playing. Whilst there was age restriction on equipment, as stated by the by-laws, these were not always adhered to. There was however a general perception that play-equipment was not appropriate for teenagers, needed or desired for this age group.

In asking a teenager what he wanted: 'A jungle gym for bigger people to play on!'

The park also provided a space which allowed for leisure activities that were not regarded as particularly physical in nature, and that provided a sense of stillness and 
rejuvenation. This included (but was not limited to) a space to talk or relax, a space to pass time, read or connect more intimately with others (i.e. couples). This subdued time use was also seen in school children who walked around the park listening to music on their cell phones. There were many instances when people were observed to be sitting, sometimes with their eyes closed, and often remaining very still for periods of time.

'I think it just gives you time to get calm, and not have to be rushing around and doing anything.'

There were many observations of children using code names in play, speaking their own language in an imaginary world, pretending the equipment was a castle or a jail or inventing new games. Natural material was also often used in creative ways, which was recognised as extremely important by the parents.

'I think there are too many children that are handed devices and [told] 'do your thing'. I don't think children are actually brought out often enough to come and play. Um, to climb a jungle gym, to walk up a slide and slide down...you know I think, I really think that all children should be encouraged. I think that the television should be switched off at home, um, or maybe allowed for a certain period of time. But I think outdoor play is extremely important. I think children are losing something, I don't know enough about it, but um, I can just see in the way children behave today how different it is.'

The researchers observed that the type of play children engaged in involved many physical and mental performance components. Gross motor play such as climbing on equipment and running around was considered by many adults to be beneficial to the child's physical and socio-emotional development, particularly in developing bravery and courage. Falling was also considered by adults to be part of growing up and learning. This indicated how the park provided a space for risks and challenges that children could learn from. 
'Jump from log to log and it's, you learn physical and you learn bravery and courage and all that kind of thing.'

II think it's very good for him, it just gives him some exercise. He loves running so he just runs on the grass. Um...I think it is very good for your development.'

Opportunities to learn about nature were also present in the park such as labelled trees, which allowed older children and adults who were interested to learn about them.

'It is very good for them, yeah, like you get to see stuff here that you wouldn't see at home, like the owls in the trees or the squirrels.'

The park also seemed to provide a space for children to develop their social skills such as sharing by learning from older children, parents, or caregivers. Often the park equipment itself encouraged engagement between children, as they were not seen interacting with new children of different ages, races or genders outside of play. When children from different families wanted to play on the same equipment, parents sometimes tried to encourage social engagement between the children. This often began awkwardly, but conversing became easier through play. It was also observed that older children were able to identify cues that a game was too difficult for the younger ones and were able to adapt so that the younger ones could still keep up and be included in play.

\section{Play: Disrupting Class and Race}

Amber Park facilitated play in various ways which again overcame social barriers that separated and divided people in the park. The park provided a neutral territory where people crossed the invisible barriers that were prevalent in other areas of the park.

The researchers found that whilst children seemed to play and interact with anyone on the same piece of equipment, adults often tended to stand awkwardly next to the equipment and not interact with each other. Parents usually interacted by means of 
greetings or small talk, and this interaction appeared to be more likely to occur when parents were of a similar class, race, age or gender or were parents of children who attended the same school. It was observed, however, that parents or caregivers were more likely to interact if their children were playing on the same equipment.

Amber Park was multi-racial and many people claimed to be very open to relationships with anyone. Despite this, very few inter-racial, intergenerational or transgender interactions were observed in the park. This observation was shared by several park users who noted racial separation in the park. Whilst there was diversity in who attended the park, groups tended to be homogenous, particularly with regards to race within interaction spaces. This homogeneity, however, was broken most commonly by children, during sharing of equipment or play spaces. Several such instances of heterogeneous groupings during play were observed, and these were mainly related to impromptu sports games.

The relationships between predominantly black nannies and white children in the park were observed to be almost always very positive. Nannies engaged in play with the children in a very supportive and encouraging way, giving verbal feedback when appropriate and also knowing when to step back and allow an internal locus of control within the children, thereby allowing the children to take charge of their play and lead it themselves. This was not always observed when parents played with their children. Often the nannies arrived in groups and sat in those groups as the children played with one another, supporting the play when needed. This was a time for socialising for both the nannies and the children and nannies tended to stay for much longer periods at the park.

'When it's snack time we just sit and then talk and talk...it's also time for us.'

Nannies were also often seen caring for children they had not come to the park with or were seen facilitating play between other children and their own charge. This interaction fostered a communal environment. 
'We are mamas, we are their mamas. We look after the kids - all of us. If I can't run to fetch them, the other lady will run and bring it to me.'

Very few interactions between a nanny and anyone who is not also a nanny or a child took place, including the parents of the nanny's charge if both came to the park. The few interactions that were observed tended to take place in the baby pen. The play that was facilitated by nannies was almost always loud, affective, child-initiated and very social. A clear delight in the play could be observed as well as what appeared to be a strong relationship between the nanny and child.

Amber Park seemed to be an equalising space for differences, thus allowed for social interaction and inclusion that may not have happened in other less equal spaces. Individuals reported making acquaintances with regular attendance, suggesting the park acted as a safe space to interact without the fear of being too well known. Often this included individuals beyond people's usual social circles such as the homeless, who would have normally been seen as a nuisance or scary. The homeless were not overtly excluded from the park community.

'Nothing must be changed. Because here they don't say 'mustn't go here'

'They like us, well, me! (laughs)'

'So you see, it's the only place we enjoy to stay around here, because we can't stay around that door, that door, that door...And to add more, uh, l've got some friends here, you see. They stay in the houses (gestures to houses across the road), so we make some friend-friendship group.'

These words began to suggest how the park provided a space that allowed for begging to be seen as something other than a nuisance or "freaky". Begging in the park was not criminalised whereas going door-to-door was seen as unacceptable. 


\section{All welcome, but...}

The third and final theme centres on the social inclusion aspect of the research question.

All welcome, but [please seem respectable according to our standards]. The researchers observed that there was an unsaid way that people must carry themselves when they visited the park. The researchers identified that there was a lot of white influence present in the park, which had to do with the location of the park and the demographics indicated by the census present in the area surrounding the park. The park offered a variety of occupations to the public that were typically seen as Western occupations or that were practised exclusively by white people in the past. Activities such as jogging, picnics, dogwalking, and tree tagging in the arboretum were some examples of activities that may have been seen to uphold whiteness and exclude people from the park who would rather use it in a different way.

All welcome, but [l'll stick to my group, thank you]. The researchers found that similarities, often clearly defined external differences such as race, gender and age often formed groups or delineated who interacted with whom. It was observed that often when families came to the park they remained as a unit and were not likely to engage with other people in the park. It was often observed that the groups present in the park (such as nannies) remained homogenous in their race, gender and ability and were more likely to interact with similar groups.

All welcome, but [we may not know how to include you]. It was clearly identified that in Amber Park all people were welcome, however, not always included or integrated into the park. This was especially evident for people with disabilities and it was reported that people with disabilities rarely interacted with other park users.

"He would love to [play with others], but I think the other kids are scared of him." 
All welcome, but [keep your distance, please]. Homeless people often frequented Amber Park.

The latent content of the data collected suggested that the park was a respectable place and thus people should behave accordingly. The ward councillor said that while vagrancy and homelessness were viewed as "antisocial behaviour", it was one of the "minor issues" that had to be dealt with in the park.

'This one specifically cuz there's not many scary looking people around here so I mean this place is quite nice.'

People felt that as long as the homeless people did not 'make a nuisance of themselves', park users were able to tolerate their presence. Previously, homeless people were also found responsible for removing items from the park, such as wood and using the public toilet facilities, which park users and park management deemed inappropriate in addition to it posing as a potential safety risk. One interviewee said that it would be useful if there could be a tap placed in the park but she feared that it would attract people who may not have access to water, such as the homeless.

A homeless man who was interviewed said, 'I stay away, far away from them. I don't disturb people.'

Thus, he, along with other homeless people, use the park and are tolerated as long as they keep their distance and do not overstep the unspoken norms of the park.

All welcome, but [look busy, please]. There was a general sense that if a person(s) was in the park they needed to have a purpose for being there, or at least look as though they did. Coming to the park alone was also perceived as strange and cause for suspicion.

I think one has to accept that it's an open park and it's for everybody... but one needs to be careful I think.' 'Sometimes there is some strange people hanging around 
and then we feel unsafe.' 'If I see someone hovering I will always go over and say, 'Excuse me, can I help you? Are you waiting for somebody?'

\section{Discussion}

\section{Park as occupational space: Enablers to meet occupational needs through valued play}

The rhetoric of play as progress (Sutton-Smith, 1997), where play is encouraged as an avenue for development was mentioned by almost all parents and was clearly valued. This is likely to be the most dominant rhetoric on play advanced in Amber Park as play space, and as such there were fixed ideas on what this play should look like. Specific types and aspects of play were encouraged which influenced how children played.

The theme 'A Space for Valued Play' provides a conceptual link between valued play and what Doble and Santha (2008) describe as occupational needs. Beyond stimulating development and growth, meeting occupational needs intersects with health and well-being. Veitch, Salmon and Ball (2007) highlight that too much focus on ageappropriate equipment often misses important aspects to meeting children's needs. Beyond merely providing a physical space, a park that facilitates restoration or rejuvenation or other occupational needs contributes to health and well-being (Doble \& Santha, 2008). The occupational needs to which the most meaning was attributed in Amber Park were those of coherence (linking past, present and future), agency (ability to choose occupational engagement), rejuvenation (a break from everyday activities or escape) and pleasure. In particular agency, rejuvenation and pleasure speak closely to the rhetoric of play as self. This involves choosing play occupations (often solitary) that allow for an expression of self through restoration and pleasure, if this is what is needed, often involving risky or dare-devil activities, depending on the person (Sutton-Smith, 1997). It often incorporates an element of escape and as such people who are unable to engage in play as a form of meaningful self-expression may be deprived of an escape or 
experiences that validate their sense of self. So through playing in Amber Park, people may begin to construct positive occupational identities, influencing their well-being.

An important question addressed in the current study regards what exactly about Amber Park allows for valued play to occur and whether this is a unique characteristic of Amber Park. Cohen, Sehgal, Williamson, Marsh, Golinelli, and McKenzie (2009) emphasise that both the physical and social aspects of a park influence the way in which it is used. Some aspects of Amber Park that are prerequisites for using the park (Cohen et al., 2009), without which valued play cannot occur included the perception of it being well-maintained (McCormack, Rock, Toohey, \& Hignell, 2010; Bedimo-Rung, Mowen \& Cohen, 2005). There was a high level of community involvement in the park which enables users to take ownership of it and together with the park committee shaped it into a space that was valuable to them. Perceptions of safety differed within Amber Park, where people generally felt safe but were cautious about what times they used the park as well as who was present in the park.

According to Sutton-Smith (1997), the rhetoric of play as imaginary involves fanciful, unreal and visionary play that involves the creation of something new. Amber Park provided many natural resources (eg. grass, trees, a stream, logs, etc.). Children were also able to use these resources to create imaginary worlds.

According to Cohen et al. (2009), many adults are not as drawn to parks as children due to the lack of inclusion for them in the design of parks. However, the presence of many adults in Amber Park engaging in play with their children or in other leisure occupations suggested that the park provided opportunities to engage in a range of activities and catered for different ages, thus contributing to the park being appealing to both children and adults who go to the park with different intentions. Veitch et al. (2007) indicate how children express the desire for a place where they can play outdoors, free from adult rules, whereas Amber Park seemed to be more of a space for family time and intergenerational play. 
Very little research has been done on urban parks meeting occupational needs and providing opportunity to engage in valued play. It is therefore difficult to say whether or not this is unique to Amber Park. However, the findings may serve as a basis for further research in order to develop criteria for what is needed in urban parks to allow for occupational needs to be met and to allow for valued play.

\section{Park as space for positive disruption through play}

The second theme of "Play: Disrupting Class and Race" is a finding not found in literature previously and possibly has great implications for understanding the power of play and how it can be used to overcome broader societal barriers. This was seen in both young children and adults, particularly through the positive relationships they formed with one another. It was also seen through a homeless man, Paul* (a pseudonym for the sake of confidentiality), who was able to use play and the park as an equalizing space to engage with people on a much more level footing and form relationships that would not usually be available to him.

\section{Play and Prejudice}

Play as frivolity (Sutton-Smith, 1997) uncovers the way in which people when playing tend to ignore barriers that South Africa has unknowingly categorized society into. Behaviour that would otherwise be frowned upon, or be considered nonsensical in society if done by adults, was seen as acceptable in the park when playing with children e.g. adults who climbed on park equipment. The adult became child-like which disrupted the standard behaviour of adult life. Play in this manner bridged the gap between young and old and brought generations together.

Baron and Banaji (2006) found that children are more prejudiced (at least overtly so) for associating with their own social group whereas Black-Gutman and Hickson (1996) suggest that perhaps children learn to be more implicitly prejudiced as they get older. However, this does not mean they become less prejudiced. This was supported in the findings where adults appeared to be explicitly supportive of racial integration but did not 
seem to interact outside of their own social group. This prejudice is a result of contextual influences which might influence children's attitudes, such as negative images about a particular group of people that are embedded in the hegemonic culture's jokes, expressions and literature (BlackGutman \& Hickson, 1996). The way that these prejudices may be passed on is not always obvious. Castelli, De Dea and Nesdale (2008) found that the nonverbal behaviours of adults significantly influence the social attitudes of preschool children. When white parents showed any signs of uneasiness while interacting with a black adult, the child was able to detect it and would consequently also show a more negative attitude towards black people.

The social attitudes of parents may therefore be transmitted to their children through the ways in which they interact or do not interact with other park users. Adult park users identified the bond between nannies and children as the primary source of interracial mixing that occurred in the park. This is an area which needs further research. If it is known that young children's social attitude towards other races are shaped by their parents' behaviour, what would the influence of white children who are partially raised by black nannies be?

\section{Park as a Levelling Plane and Playing Difference Away}

Parks offer spaces in which people are able to integrate on equal levels in a nondemanding way (Kazmierczak \& James, 2007). Kazmierczak and James (2007) further suggest that green spaces of quality foster community development as well as social inclusion, with this being due to the fact that these spaces are open to the public and equally available to anyone. This speaks into the difficult situation faced by homeless people where often a public place such as Amber Park might be the only place for them to go (Mitchell, 2010).

One example of this was with Paul, the homeless man who spent a lot of time at the park begging. His occupation of begging was not regarded as strange or threatening as many park users would often associate with homeless people. A study by Daiski (2007) found that the homeless reported struggling the most with feeling invisible and excluded 
from society, resulting in a low self-esteem, which is a very different picture to Paul, a seemingly positive and content person who felt fulfilled in the relationships he has formed in the park. Paul suggested that this was because he did not disturb people in their homes, proposing that the park itself along with being able to act "normally" within it (not disturbing people in the park e.g. begging at parties) that provided him with much more equal footing in being able to engage with people and feel a sense of community.

The park as an equalising space alone, however, was not enough to overcome the barriers, as other homeless people who lived on the outskirts of the park did not seem to hang around in the park during the day and did not appear to be included in the park in the same manner that Paul was. This suggested that this man's playful manner and jovial tone may have played a part in allowing him to be "the exception" to the perceptions around homeless people in the area. He described friendships being formed and feeling safe in the park. This may be understood through the lens of play as frivolity (SuttonSmith, 1997), where Paul used language in a playful manner, joking and laughing to build relationships with other park users and was thus seen very differently from other homeless people. In viewing this it was possible to describe play as a contributing factor in breaking the barrier of being seen as a homeless man and instead being viewed as a legitimate citizen.

Children were observed playing with many "different" children with no distinctions made between race, class or age. This may mean that despite being prejudiced or having environmental factors impacting their prejudice, play was something that allowed for this to be put aside and act as a means of overcoming these prejudices. The rhetoric of play as frivolity explores ways that play can subvert the status quo. This is distinct for play, and there were no other findings outside of play in which children were seen to be more inclusive than their parents in Amber Park.

Occupational consciousness (Ramugondo, 2015) is a conceptual tool that allows people to realise how their everyday familiar occupations are able to break down the social barriers they confront. It works by using everyday occupations such as play, as a 
language to acknowledge differences and overcome the often unseen oppressive structures (Ramugondo, 2015). This is a form of counter-hegemonic engagement that challenges the unseen and unquestioned practices. In the park, users may be able to engage in frivolous play or use adult forms of play (such as sport and recreation) to break down barriers. In raising awareness about this, it may also raise consciousness around who is being excluded from meaningful occupations and the ways in which park users together can create a more inclusive environment.

\section{Park providing an accessible, but not always inclusive space}

The third theme of 'All welcome, but...' discusses how accessibility differed from inclusion and the way in which the park included and excluded certain groups with invisible norms and standards that were not always visible to those within those norms and standards. Challenging these assumptions and norms may allow for a more inclusive community that benefits everyone and increases intercultural learning.

\section{Accessible for Dominant Groups}

At first sight Amber Park seemed to be a racially integrated park as people of all races and cultures utilized the park. People at Amber Park socialized in homogeneous groups or with individuals of similar characteristics such as gender, age, and most commonly race. This is supported by what McPherson, Smith-Lovin and Cook (2001) refer to as homophily - the principle that more contact occurs between similar people than among dissimilar people and that the greatest division in personal environments is the homophily in race and ethnicity.

According to Low, Taplin and Scheld (2005), many parks are starting to become less accessible to everyone and are beginning to exclude particular groupings. Consequently, there is a decrease in vibrancy, causing members of society to begin thinking that only one type of person is able to make use of the park. 


\section{How Hegemony is Maintained}

It became apparent that there were implicit expectations of how one should behave in the park that are in line with the dominant (white) group's values. This was an indication of how whiteness was within the park, through the way in which people felt they had to act and how some identities were profiled as strange or scary. The park offered a huge variety of occupations to the public and the occupations that were seen were all originally Western and done by white people. The park had no visible deterrent for multi-cultural occupations to occur, so one may ask why 'Undize' or 'Stenana' (traditional Xhosa games) were not seen played in the park.

Unfortunately there were no interviews with park users that explored whiteness or the way that it manifested in the park, perhaps because of the fact that all the researchers were white, eliciting restricted opportunities for authentic engagement across cultures.

Ramugondo (2012) discusses how adults in particular can enforce a specific dominant rhetoric of play, and this possibly creates expectations around what play should look like in the park. The effects of this may be more significant than one may think, in that children were unable to form coherent occupational narratives of play consistent with previous generations within their culture, as the dominant rhetoric of the park did not encourage different forms of play. This links to the need for coherence (Doble \& Santha, 2008), where parents' and children's play formed one varying but continuous narrative over time. There was a further disruption in the occupational narratives formed between nannies and their children, as the way in which the nannies were required to play with the white children was different to what they reported playing themselves as children.

\section{Who is not Included?}

Single people, especially men, who did not appear to have had a set purpose for being in the park seemed to be considered by park users as strange and a threat to their safety. While the reasons for feeling unsafe with strange people in Amber Park were not made explicit by park users, one can assume that this fear was likely to stem from the 
violent nature of this country and where crime is often associated with certain types of people. Further reading into this topic suggests that social interaction is affected by characteristics of the individual.

Every individual experiences exclusion in a different way (Kotze, 2003). People with disabilities was another group that was not considered to be socially included in the park. The majority of work surrounding inclusion in literature has been on making public spaces more accessible for people with disabilities (Brorsson, Ohman, Lundberg, \& Nygard, 2011). However, physically accommodating them in the environment alone does not allow them access to the social, cultural and aspects of the park. The social model of disability, states that disability is located within oppressive environments and by challenging these, oppression can be removed or alleviated (Marks, 1999). Ryan (2005) found that mothers of children with disabilities are likely to be stared at or asked questions. However, the author found this an understandable response to difference and challenges disability advocates to use this to initiate awareness raising campaigns. Could this be the key to social inclusion for people with disabilities, and does Amber Park provide a space for this kind of dialogue to be held? The question of what can be done, in addition to physical access, to provide a truly inclusive social space for people with disabilities needs to be explored in more depth.

\section{Conclusion}

Many parks, as reported in literature, do not necessarily facilitate valued play. This study found that Amber Park was one of the few parks that supported valued play, as it provided many physical, social and emotional benefits, particularly in fulfilling occupational needs. The importance of play in bringing coherence to parents regarding their children's play and the meaning that it personally had for them within the dominant rhetoric of play as progress and the imaginary, is a key finding about how Amber Park facilitated intergenerational play. In being well-utilised, Amber Park provided a supportive structure for play engagement that allowed for meeting needs and social inclusion. The park facilitated social inclusion by bringing people together that may not usually meet, where they were able to have contact, be it fleeting or longer-lasting. Amber Park tended 
to be very open and accessible, however, it was not as inclusive as it could be (where hegemonic discourses shaped many of the occupations that occurred there) and only certain groups may have felt they belonged. This study revealed how homeless and disabled people in particular, although present in the park, were not considered to belong or provided with adequate support to play and socialise.

Amber Park, however, offered play as a unique way to bridge the divide between groups that may not otherwise interact in their daily lives due to difference. This new finding showed how play itself may overcome prejudice. This study contributes to the limited knowledge on play in parks and urban spaces, as well as highlights several new findings that may have a significant impact in the South African context of ongoing racial division and separation. This information is important for collaboration and policy-making and can inform interdisciplinary work.

\section{References}

Baron, A. S., \& Banaji, M. R. (2006). The Development of Implicit Attitudes. Evidence of Race Evaluations From Ages 6 and 10 and Adulthood. Psychological Science, 17(1), 5358. http://doi.org/10.1111/j.1467-9280.2005.01664.x

Bedimo-Rung, A. L., Mowen, A. J., \& Cohen, D. A. (2005). The Significance of Parks to Physical Activity and Public Health. American Journal of Preventive Medicine, 28(2S2), 159-168. http://doi.org/10.1016/j.ampre.2004.10.024

Black-Gutman, D., \& Hickson, F. (1996). The relationship between racial attitudes and social-cognitive development in children: An Australian study. Developmental Psychology, 32(3), 448-456. http://doi.org/10.1037/0012-1649.32.3.448

Brorsson, A., Ohman, A., Lundberg, S., \& Nygard, L. (2011). Accessibility in public space as perceived by people with Alzheimer's disease. Dementia, 10(4), 587-602. http://doi.org/10.1177/1471301211415314 
Burton, E. (2011). The importance of the built environment to children's well-being: what do we know? In Cities, Health and Well-being (pp. 1-4). Hong Kong: Urban Age.

Castelli, L., De Dea, C., \& Nesdale, D. (2008). Learning social attitudes: children's sensitivity to the nonverbal behaviors of adult models during interracial interactions. Personality and Social Psychology Bulletin, 34(11), 1504-1513. http://doi.org/10.1177/0146167208322769

Cohen, D. A., Sehgal, A., Williamson, S., Marsh, T., Golinelli, D., \& McKenzie, T. L. (2009). New recreational facilities for the young and the old in Los Angeles: policy and programming implications. Journal of Public Health Policy, 30(Supp 1), S248-S263. http://doi.org/10.1057/jphp.2008.45

Daiski, I. (2007). Perspectives of homeless people on their health and health needs priorities. Journal of Advanced Nursing, 58(3), 273-281. http://doi.org/10.1111/j.13652648.2007.04234.x

Doble, S. E., \& Santha, J. C. (2008). Occupational well-being: rethinking occupational therapy outcomes. Canadian Journal of Occupational Therapyherapy, 75(3), 184-190. http://doi.org/10.1177/000841740807500310

Frost, J., \& Klein, B. (1979). Children's play and playgrounds. Boston, MA: Allyn \& Bacon.

Kazmierczak, A., \& James, P. (2007). The role of urban green spaces in improving social inclusion. Landscape and Urban Planning. Retrieved from http://usir.salford.ac.uk/11339/

Knox, S. (2008). Development and Current Use of the Revised Knox Preschool Play Scale. In L. D. Parham \& L. S. Fazio (Eds.), Play in Occupational Therapy for Children (pp. 55-70). St Louis, Missouri: Mosby Elsevier. 
Kotze, N. (2003). The inclusion of South Africans with Disabilities in Public Space: A Bloemfontein Case Study. Urban Forum, 14(4), 366-378. http://doi.org/10.1007/s12132003-0019-4

Loukaitou-Sideris, A., \& Sideris, A. (2009). What Brings Children to the Park? Analysis and Measurement of the Variables Affecting Children's Use of Parks. Journal of the American Planning Association, 76(1), 89-107. http://doi.org/10.1080/01944360903418338

Low, S., Taplin, D., \& Scheld, S. (2005). Rethinking Urban Parks: Public Space and Cultural Diversity (1st ed.). Austin, Texas: University of Texas Press.

Luchs, A., \& Fikus, M. (2013). A comparative study of active play on differently designed playgrounds. Journal of Adventure Education \& Outdoor Learning, 13(3), 206-222. http://doi.org/10.1080/14729679.2013.778784

Marks, D. (1999). Dimensions of Oppression: Theorising the embodied subject. Disability \& Society, 14(5), 611-626. http://doi.org/10.1080/09687599925975

McCormack, G. R., Rock, M., Toohey, A. M., \& Hignell, D. (2010). Characteristics of urban parks associated with park use and physical activity: A review of qualitative research. Health and Place, 16(4), 712-726. http://doi.org/10.1016/j.healthplace.2010.03.003

McPherson, M., Smith-Lovin, L., \& Cook, J. M. (2001). Birds of a Feather: Homophily in Social Networks. Annual Review of Sociology, 27(1), 415-444. http://doi.org/10.1146/annurev.soc.27.1.415

Mitchell, D. (2010). Anti-Homeless Laws and Public Space: II. Further Constitutional Issues. Urban Geography, 19(2), 98-104. http://doi.org/10.2747/0272-3638.19.2.98

Pellegrini, A. D. (1995). School recess and playground behaviour: Educational and development roles. Albany, NY: State University of New York Press. 
Ramugondo, E. L. (2012). Intergenerational Play within Family: The Case for Occupational Consciousness. Journal of Occupational Science, 19(4), 326-340. http://doi.org/10.1080/14427591.2012.710166

Ramugondo, E. L. (2015). Occupational Consciousness. Journal of Occupational Science, (August), 1-14. http://doi.org/10.1080/14427591.2015.1042516

Shackell, A., Butler, N., Doyle, P., \& Ball, D. (2008). Design for Play: A guide to creating successful play spaces. Nottingham: DCSF Publications. Retrieved from http://eprints.mdx.ac.uk/5028/

Strategic Development Information and GIS Department. (2013). City of Cape Town 2011 Census Suburb Rondebosch/Rosebank 2011. Cape Town. Retrieved from https://www.capetown.gov.za/en/stats/2011CensusSuburbs/2011 Census CT Suburb Rondebosch_Rosebank_Profile.pdf

Sutton-Smith, B. (1997). The Ambiguity of Play. Cambridge, MA: Harvard University Press.

Sutton-Smith, B. (2006). Play and Ambiguity. In K. Salen \& E. Zimmerman (Eds.), The Game Design Reader: A Rules of Play Anthology (pp. 296-313). US: Massachusetts Institute of Technology.

Tewksbury, R. (2009). Qualitative versus Quantitative Methods: Understanding Why Qualitative Methods are Superior for Criminology and Criminal Justice. Journal of Theoretical and Philosophical Criminology, 1(1), 38-58. Retrieved from http://jtpcrim.org/January_Articles/Qualitative_Vs_Quantitave_Richard_Tewksbury.pdf 
Open Access available at: http://journals.uct.ac.za/index.php/UR

DOI 10.15641/ur-at-uct.v1i2.37

Veitch, J., Salmon, J., \& Ball, K. (2007). Children's Perceptions of the Use of Public Open

Spaces for Active Free-play. Children's Geographies, 5(4), 409-422. http://doi.org/10.1080/14733280701631874

Wilcock, A. A. (2006). An Occupational Perspective of Health (2nd ed.). Thorofare, New Jersey: SLACK Incorporated. 